\title{
P02.195. Acupuncture for acute pain management in an emergency department: an observational study
}

\author{
T Zhang $^{1^{*}}$, D Smit ${ }^{2}$, D Taylor ${ }^{3}$, S Parker $^{1}$, C Xue $^{1}$ \\ From International Research Congress on Integrative Medicine and Health 2012 \\ Portland, Oregon, USA. 15-18 May 2012
}

\section{Purpose}

To evaluate the impact on clinical outcomes by providing acupuncture as an option for acute pain management in the emergency department (ED) of a major metropolitan hospital in Melbourne, Australia.

\section{Methods}

Adult patients (aged 18+ years) with acute pain attending the ED were initially assessed by medical staff and/or acupuncture staff for the suitability of acupuncture treatment. A total of 200 patients received acupuncture treatment. The selection of points for treatment was based on Chinese medicine diagnosis and theory. The treatment duration was 30 minutes on average with or without electrical stimulation. A Visual Analogue Scale (VAS) to measure pain scores before and after acupuncture treatment was the primary outcome.

\section{Results}

Pain in the abdominal or flank region and muscle and musculoskeletal related pain were the common conditions treated (83\%). A significant difference in the scores of before $($ mean $=7.01)$ and post treatment $($ mean $=$ 4.72) was observed $[\mathrm{t}(193)=14.81, \mathrm{p}<.001]$. Four patients $(2 \%)$ reported adverse events during the course of the acupuncture treatment. These included two cases of slight bleeding with the other two cases of mild pain at the needling sites. No serious adverse events were reported. More than half (52.5\%) of patients indicated that they would definitely consider acupuncture in the future for the same health condition and a further

${ }^{1}$ RMIT University, Australia, Melbourne, Australia

Full list of author information is available at the end of the article
$31.8 \%$ said they probably would consider acupuncture again.

\section{Conclusion}

Acupuncture can be an effective and safe adjunct intervention for patients with acute pain in settings such as the emergency pain management environment.

\section{Author details}

${ }^{1}$ RMIT University, Australia, Melbourne, Australia. ${ }^{2}$ Alfred Hospital, Melbourne, Australia. ${ }^{3}$ Austin Hospital, Melbourne, Australia.

Published: 12 June 2012

doi:10.1186/1472-6882-12-S1-P251

Cite this article as: Zhang et al:: P02.195. Acupuncture for acute pain management in an emergency department: an observational study. BMC Complementary and Alternative Medicine 2012 12(Suppl 1):P251.

Submit your next manuscript to BioMed Central and take full advantage of:

- Convenient online submission

- Thorough peer review

- No space constraints or color figure charges

- Immediate publication on acceptance

- Inclusion in PubMed, CAS, Scopus and Google Scholar

- Research which is freely available for redistribution
C Biomed Central

C 2012 Zhang et al; licensee BioMed Central Ltd. This is an Open Access article distributed under the terms of the Creative Commons Attribution License (http://creativecommons.org/licenses/by/2.0), which permits unrestricted use, distribution, and reproduction in any medium, provided the original work is properly cited. 